\title{
Exploring the Yeast Diversity of Common Alcoholic Beverages of Assam
}

\author{
B. Saikia*, M.S. Ali, P.D. Nath and P.C. Dey \\ Department of Plant Pathology, Assam Agricultural University, Jorhat-785013, Assam, India \\ *Corresponding author
}

\section{A B S T R A C T}

\section{Keywords}

Starter culture, Saccharomyces cerevisiae, Saccharomycopsis fibuligera, Candida $\mathrm{sp}$

\section{Article Info}

Accepted: 15 April 2019 Available Online: 10 May 2019
Rice is a major crop of Assam. Using rice as a substrate, different communities in the state produces peculiar fermented and non-fermented products like rice beer, sweets and snacks etc. Production of rice beer involves two steps; starter culture preparation and brewing. The starter culture is made of rice and herbal combinations and believed to act as inoculants for brewing. These products often contain mixed microbial population due to allowance of natural fermentation. Some amylolytic fungi plays important role in saccharification, whereas yeast is the dominant fermenting agent of glucose to produce ethanol. Besides, these products often contain wild yeast and other microbial population due to allowance of natural fermentation which have a significant impact on food quality. A study was undertaken to systematically study the fungi associated with rice beer starter culture. Thirty two yeasts were isolated from twelve rice beer starter cultures collected from six different districts viz., Jorhat, Sivasagar, Golaghat, Lakhimpur, Dhemaji and Majuli. Morphological identification was carried out with the help of standard literature. Macro- and micromorphological studies revealed the most frequently associated yeasts species viz., Saccharomyces cerevisiae, Saccharomycopsis fibuligera and Candida spp.

\section{Introduction}

Assam is one of the states in North East India, situated south of the Eastern Himalayas. The climate is temperate to sub-tropical with summer maximum temperature $35-38{ }^{\circ} \mathrm{C}$ and winter minimum $6-8{ }^{\circ} \mathrm{C}$, high relative humidity and annual rainfall of average 2500 $\mathrm{mm}$ to $4500 \mathrm{~mm}$ per annum. Assam is traditionally a rice growing state. Out of total 4 million hectare cultivated area 25 lakh ha is under rice cultivation with a production of $2093 \mathrm{~kg} / \mathrm{ha}$ where national average is 104.32 $\mathrm{mt}$, area $43.87 \mathrm{mha}$ and productivity of 2381 $\mathrm{kg} / \mathrm{ha}$ (Anon, 2016). Rice plays a pivotal role in the socio-cultural life of the people of the state. As a traditional practice, rice is processed into rice beer, which is of both ethnic and possible commercial importance (Ahmed et al., 2010; Dutta and Mahanta, 2014).

Assam is inhabited by many indigenous tribes and as part of their socio-cultural lives; most of the tribes prepare their own household alcoholic beverages using rice as a substrate. The alcoholic beverage is used in various traditional ceremonies, religious rituals and also considered to posses medicinal and therapeutic properties. These products are 
similar to shaosingiju of China; sake of Japan; chongju and takju of Korea; brem bali, tapeketan and tapuy of Indonesia, khaomak of Thailand and tapai pulul of Malaysia (Xie et al., 2007). Moreover, different tribes of Assam like; Ahom, Deori, Mishing, etc. have their own unique rice based alcoholic beverages known as haj, suzen, apong, respectively. These three major tribal beverages were focused in this study.

Basically, rice wine manufacturing consist of saccharification of steamed rice starch by fungal enzymes under aerobic solid state fermentation and the product is mixed with water and is allowed to undergo submerged alcoholic fermentation by yeasts using traditional starter cakes (Sujaya et al., 2004; Dung et al., 2006).

Variety of microorganisms naturally ferment majority of global fermented foods and beverages. Bacteria, yeast and mycelial fungi are mainly associated with fermentation. Yeast can be present alone or in a stable mixed population with mycelial fungi or bacteria and have a significant impact on food quality. Modern breweries employ closed brewing system that reduces the risk of contamination by 'wild' yeast. However, traditionally fermented products contain mixed microbial populations because of lack of sterility and the use of natural fermentation or mix culture fermentation starters (Robert and Kofi, 2015). Wild yeasts can therefore be non-Saccharomyces yeast, Saccharomyces yeast species other than brewing production yeast, or even production yeast strains other than those intended for a specific fermentation. In other words, yeast not deliberately used and under full control (Gilliland, 1971). Beer spoilage due to the presence of wild yeast contaminants includes production of off-flavours, competition with brewing yeasts for nutrients. Therefore, understanding of yeast mycoflora present in the traditional rice beer is necessary to take decisions regarding the optimization of processes to eliminate unwanted yeast contaminants and thus prevent unnecessary beer spoilage.

Chakrabarty (2017) examined the yeast flora present in nduiyi, a traditional amylolytic starter used to produce alcoholic beverage called nduijao from Dima Hasao district of Assam. Based on cell morphology and phenotypic characterization isolates were identified as Candida glabrata and Saccharomyces cerevisiae. A metagenomic study revealed the microbial community associated with $h a j$, a traditional alcoholic beverage of Ahom tribe of Assam. The existence of ethanol producers viz., Meyerozyma guilliermondii, Wickerhamomyces ciferrii, Saccharomyces cerevisiae, Candida glabrata, Debaryomyces hansenii, Ogataea parapolymorpha and Dekkera bruxellensis, were found associated with the starter culture along with a diverse range of opportunistic contaminants (Bora $e t$ al., 2016). Literature is meagre with respect to yeast taxonomical study in north east India with special reference to state of Assam.

This investigation was aimed at the morphological identification of indigenous yeasts isolates from rice beer starter culture samples. The samples were collected from Ahom, Mishing and Deori community residing in seven different districts of Assam, India.

\section{Materials and Methods}

\section{Collection of samples}

Indigenously prepared rice beer starter cultures viz., xaj, apong, suzen were collected in sterilized plastic bags and brought to laboratory for isolation of associated mycoflora. 
Isolation of yeasts and fungi from starter culture

Rice starter cultures were ground to fine powder with the help of electric grinder (Bhuyan and Baishya, 2013) and 10g of sample is suspended in $90 \mathrm{ml}$ sterilized water and mixed thoroughly. $1 \mathrm{ml}$ solution was serially diluted to $10^{-4}$ and $10^{-5}$. Each dilution was spread onto potato dextrose agar (PDA) supplemented with 200ppm streptomycin sulphate and incubated at $25 \pm 1^{\circ} \mathrm{c}$ for 48 hours. Individual yeasts colonies with distinct colony and morphological characters were picked up and repeatedly streaked in yeast extract peptone dextrose (YEPD) agar media (Jeyaram et al., 2008) and maintained.

\section{Cultural and morphological identification of yeasts}

Each of the purified colonies of yeasts was grown on yeast extract peptone dextrose (YEPD) agar for assessing their colony characteristics mostly shape, colour, margin, texture (Chavan et al., 2009; Goralska, 2011; Spencer et al., 2011). To induce ascospore formation yeasts isolates were cultured on V8 juice agar (Yarrow, 1998; Barnett et al., 2000).

Microscopic characteristics of yeasts viz., cell shape, size, presence/absence of budding and pseudohyphae, sexual stage, shape and size of ascus and ascospore if present was studied by lacto phenol cotton blue and basic fuchsin staining under 40 x \&100x light microscope. Whole preparation of ascus was done by moderately heating and tapping the structures, released ascospores were examined and measured. Microphotographs were taken to show the typical morphology of the fungi.

Identification and characterization of yeasts were carried out with the help of relevant keys, monograph, standard literature (Lodder,
1971; Barnett, 1990; Barnett, 2000) and CBS yeast database.

\section{Results and Discussion}

Twenty eight yeasts were identified from all the starter culture samples collected during the investigation.

\section{Morphological identification}

Saccharomyces cerevisiae isolates were found to be dominant in all the samples. It showed white to creamy colonies with smooth and butyrous growth on yeast extract peptone dextrose agar. After three days at $25 \pm 1^{\circ} \mathrm{C}$ cells are spheroidal, sub- globose, ovoid and occur singly, in pairs or sometimes in small clusters. Cell size of different isolates ranging from 1.3-3.2 $\mu \mathrm{m}$ to 4.0-5.8 $\mu \mathrm{m}$. Ascus with two to four round ascospores were typical of S. cerevisiae (Fig. 1D). Table 1 shows macro and micomorphology of S. cerevisiae isolates. Pseudohyphae or true hyphae were not observed in any of the isolates. S. cerevisiae is the major fermenting agent of all the globally fermented products.

Three isolates showed typical tough, raised and farinose, partly or entirely hairy colonies on YEPD agar (Table 2.). Based on the colony characters (Fig. 2), it was identified as Saccharomycopsis (Lindner) Klocker. The identification was further confirmed based on the micromorphological observations. The yeast was characterized by the formation of septate hyphae and multipolar budding cells. Presence of spherical to oval asci, situated at the ends of the mycelia hyphae or alongside them; bearing two to four hat shaped ascospores confirms the yeast upto species level as S. fibuligera. Clear zone formation was also observed when subjected to starch hydrolysis test, indicating the production of amylase enzyme by the yeast (Wickerham $e t$ al., 1944). S. fibuligera was reported to be the 
principal amylolytic yeasts found in Indonesian cassava-tape and ragi tape (alcoholic beverages made from cassava and ragi); that produces large amount of amylases, acid protease and $\beta$-glucosidase which have highly potential applications in fermentation industry (Chi et al., 2009). It is also used to produce ethanol from starch, especially cassava starch by co-cultures of Saccharomyces cerevisiae (Chi et al., 2009). The presence of $S$. fibuligera is thus beneficial for the beer production process.

Four Candida spp. were identified based on presence of pseudomycellium and true mycelium and absence of sexual stage. All the four isolates produced white to creamy, smooth and butyrous colonies on YEPD agar. However, the cell size and shape varies among all the isolates. The cells of one isolate were short-ovoid to ovoid $4.2-5.4 \times 6.5-8.5$ $\mu \mathrm{m}$. Pseudomycelium is abundantly formed and consist of long-stretched, branched pseudohyphae bearing blastoconidia and verticils of blastospores in branched or simple chains. True mycelium occurs. Based on these morphological characters and comparison with standard literature the yeast was identified as C. tropicalis (Fig. 3).

The other three isolates have cells of ovoid to cylindrical shape, pseudomycelium present, true mycelium not observed, reproduce by budding. The cell sizes varied between the three isolates, ranging from 2.2-3.5 x 2.8- 4.5 $\mu \mathrm{m}, 2.5-3.6 \mathrm{x} 2.5-4.8 \mu \mathrm{m}$ and $10.2-11.4 \mathrm{x}$ 10.4-15.5 $\mu \mathrm{m}$ (Table 3).

The study shows that different kinds of yeasts were associated with rice beer starter culture of Assam (Fig. 1-3).

Table.1 Macromorphology and micromorphology of Saccharomyces cerevisiae

\begin{tabular}{|c|c|c|c|c|c|c|c|}
\hline \multirow[t]{2}{*}{ Location } & \multicolumn{3}{|c|}{ Macromorphology } & \multicolumn{4}{|c|}{ Micromorphology } \\
\hline & Colour & Appreance & Texture & Cell shape & Cell size $(\mu \mathrm{m})$ & Budding & Sexual stage \\
\hline \multirow[t]{4}{*}{ Jorhat } & White & Smooth & Butyrous & $\begin{array}{l}\text { Round, } \\
\text { oval to } \\
\text { cylindrical }\end{array}$ & $\begin{array}{l}2.4-3.8 \times 2.6- \\
\quad 3.6\end{array}$ & Present & $\begin{array}{l}\text { Ascus with 1-4 } \\
\text { thin walled, } \\
\text { smooth, } \\
\text { pherical to sub- } \\
\text { spherical } \\
\text { ascospore }\end{array}$ \\
\hline & White & Smooth & Butyrous & do & $1.5-2.9 \times 2.0-3.6$ & Do & do \\
\hline & White to Creamy & Smooth & Butyrous & do & $3.2 \times 4.5-4.9$ & do & Do \\
\hline & White to Creamy & Smooth & Butyrous & do & $1.9-3.1 \times 3.1-4.5$ & do & Do \\
\hline \multirow[t]{2}{*}{ Golaghat } & White & $\begin{array}{c}\text { Smooth } \\
\text { and raised }\end{array}$ & Butyrous & do & $3.0-4.2 \times 4.1-5.2$ & do & Do \\
\hline & White to off white & Smooth & Butyrous & do & $2.3 \times 2.5-2.6$ & do & Do \\
\hline \multirow[t]{2}{*}{ Sivasagar } & White & Smooth & Butyrous & do & $3.2 \times 4.5-4.9$ & do & Do \\
\hline & White to Creamy & Smooth & Butyrous & do & $1.9-3.1 \times 3.1-4.5$ & do & Do \\
\hline \multirow[t]{3}{*}{ Lakhimpur } & White to Creamy & Smooth & Butyrous & do & $2.0-2.9 \times 2.8-4.5$ & do & Do \\
\hline & White to Creamy & Smooth & Butyrous & do & $3.8-3.9 \times 5.9-6.0$ & do & Do \\
\hline & White & Smooth & Butyrous & do & $2.9-3.0 \times 5.1-5.2$ & do & Do \\
\hline Dhemaji & White to Creamy & Smooth & Butyrous & do & $3.2-3.6 \times 5.0-5.2$ & do & Do \\
\hline Majuli & White to Creamy & Smooth & Butyrous & do & $4.0-4.7 \times 5.5-5.8$ & do & Do \\
\hline $\begin{array}{c}\text { Karbi } \\
\text { Anglong }\end{array}$ & White to Creamy & Smooth & Butyrous & do & $1.9-3.1 \times 3.1-4.5$ & do & do \\
\hline
\end{tabular}


Table.2 Macromorphology and micromorphology of Saccharomycopsis fibuligera

\begin{tabular}{|c|c|c|c|c|c|c|c|}
\hline \multirow[t]{2}{*}{ Location } & \multicolumn{3}{|c|}{ Macromorphology } & \multicolumn{4}{|c|}{ Micromorphology } \\
\hline & Colour & Appreance & Texture & $\begin{array}{l}\text { Cell } \\
\text { shape }\end{array}$ & $\begin{array}{l}\text { Cell } \\
\text { size(um) }\end{array}$ & Sexual stage & True hyphae \\
\hline \multirow[t]{2}{*}{ Jorhat } & Creamy & Farinose & Membranous & $\begin{array}{l}\text { Oval to } \\
\text { cylindrical }\end{array}$ & $\begin{array}{l}3.0-3.5 \mathrm{x} \\
3.5-4.5\end{array}$ & $\begin{array}{l}\text { Spherical to } \\
\text { ovoidal asci } \\
\text { formed on hyphal } \\
\text { structure, } 2-4 \text { hat } \\
\text { shaped ascospore }\end{array}$ & $\begin{array}{l}\text { Septate mycelium } \\
\text { present, } \\
\text { originating from } \\
\text { spore. Sexual and } \\
\text { asexual stage both } \\
\text { present together }\end{array}$ \\
\hline & $\begin{array}{l}\text { White } \\
\text { to } \\
\text { creamy }\end{array}$ & Farinose & Membranous & $\begin{array}{l}\text { Oval to } \\
\text { cylindrical }\end{array}$ & $\begin{array}{l}2.5-3.4 X \\
4.0-4.5\end{array}$ & do & do \\
\hline Golaghat & $\begin{array}{l}\text { White } \\
\text { to } \\
\text { creamy }\end{array}$ & Farinose & Membranous & $\begin{array}{l}\text { Oval to } \\
\text { cylindrical }\end{array}$ & $\begin{array}{l}2.4-3.2 X \\
3.9-4.6\end{array}$ & do & do \\
\hline
\end{tabular}

Table.3 Macromorphology and micromorphology of Candida tropicalis and Candida spp.

\begin{tabular}{|c|c|c|c|c|c|c|c|c|}
\hline & Colour & Appearance & Texture & Cell shape & $\begin{array}{c}\text { Cell } \\
\operatorname{size}(\mu \mathrm{m})\end{array}$ & Budding & $\begin{array}{c}\text { Sexual } \\
\text { stage }\end{array}$ & \\
\hline \multicolumn{9}{|c|}{ a) Candida tropicalis } \\
\hline Sivasagar & $\begin{array}{c}\text { White to } \\
\text { Creamy }\end{array}$ & Smooth & Butyrous & $\begin{array}{l}\text { Oval to } \\
\text { cylindrical }\end{array}$ & $\begin{array}{c}4.2-5.4 \mathrm{x} \\
6.5-8.5\end{array}$ & Present & Absent & Present \\
\hline \multicolumn{9}{|c|}{ b) Candida spp. } \\
\hline Jorhat & White & Smooth & Butyrous & $\begin{array}{c}\text { Ovoid } \\
\text { forming } \\
\text { short chains } \\
\text { by budding }\end{array}$ & $\begin{array}{c}2.5-3.5 \mathrm{x} \\
2.5-4.7\end{array}$ & Present & Absent & Present \\
\hline Sivasagar & $\begin{array}{l}\text { White to } \\
\text { Creamy }\end{array}$ & Smooth & Butyrous & $\begin{array}{l}\text { Oval to } \\
\text { cylindrical }\end{array}$ & $\begin{array}{c}10.2-11.3 x \\
10.3-15.5\end{array}$ & Present & Absent & Present \\
\hline Dhemaji & $\begin{array}{l}\text { White to } \\
\text { Creamy }\end{array}$ & Smooth & Butyrous & $\begin{array}{l}\text { Oval to } \\
\text { cylindrical }\end{array}$ & $\begin{array}{c}2.1-3.2 \mathrm{x} \\
2.6-4.2\end{array}$ & Present & Absent & Present \\
\hline
\end{tabular}
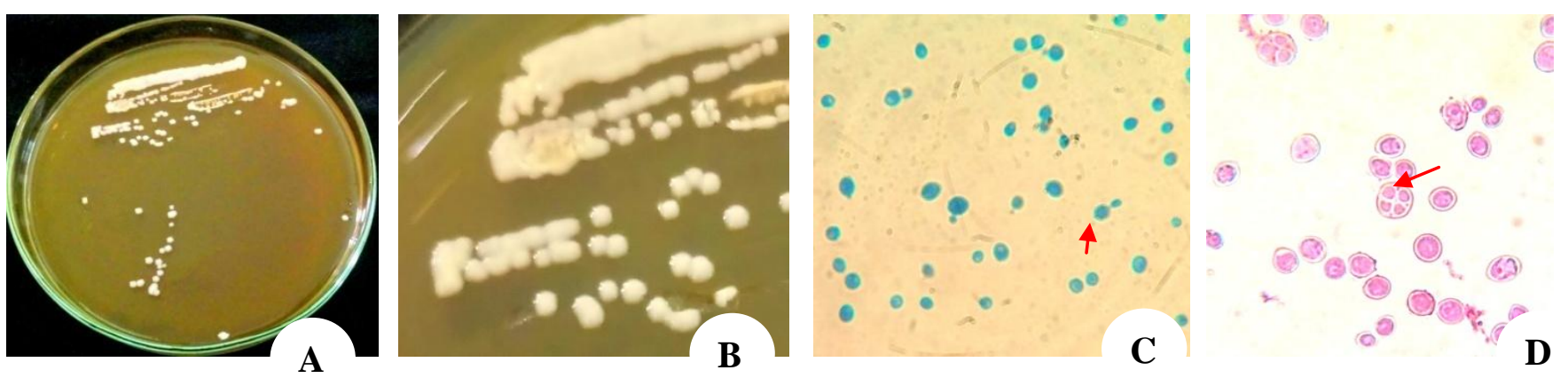

Fig.1 Macro and micromorphology of Saccharomyces cerevisiae (A-B) pure culture on YEPD agar (C)

S. Cerevisiae cells, budding (D) ascus with ascospore/ tetrads 

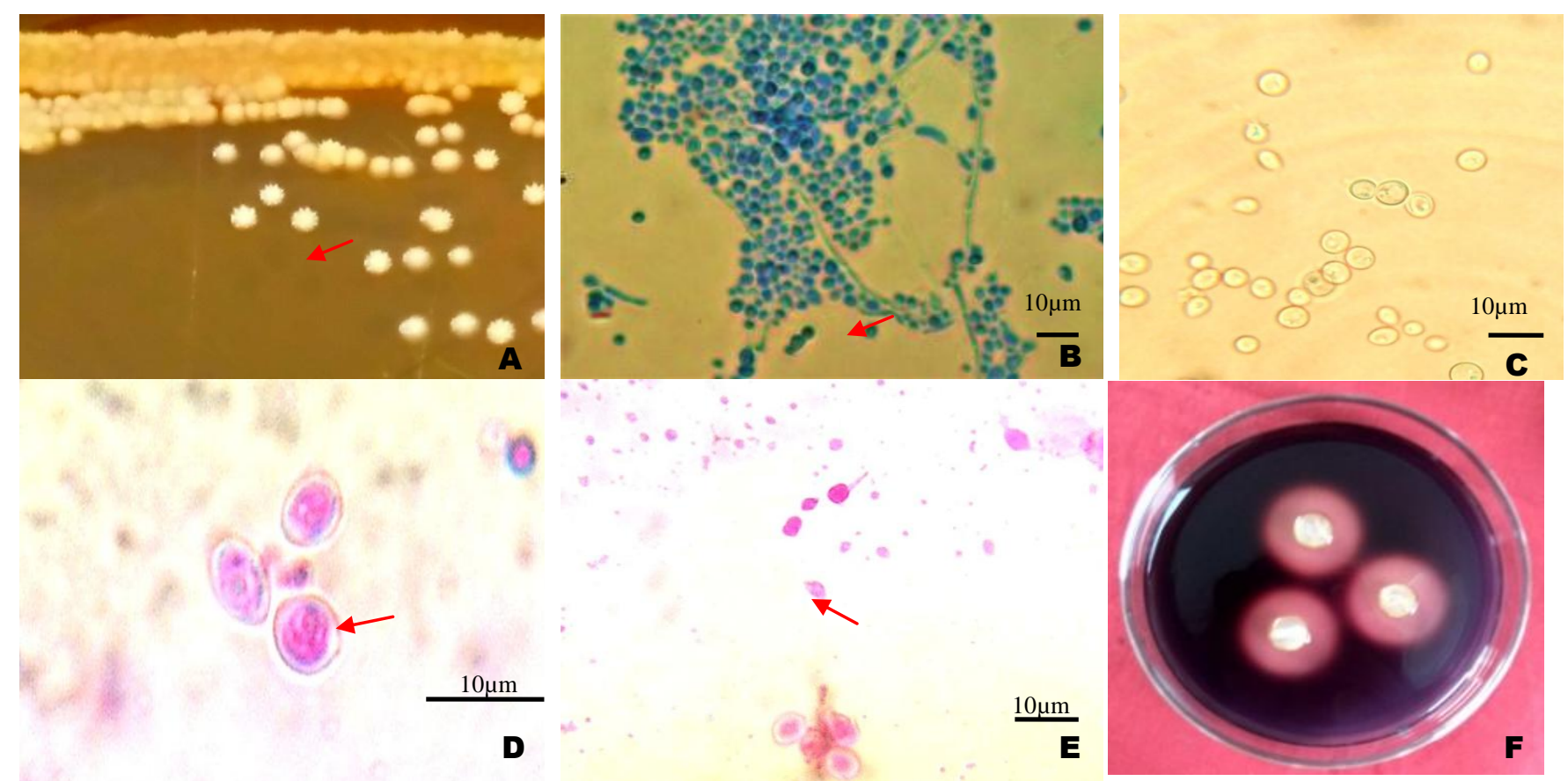

Fig.2 Macro and micro morphology of Saccharomycopsis fibuligera
(A) farinose colonies on yepd agar
(B) pseudo and true hyphae
(C) budding cells

(D) ascus with ascospores

(E) hat shaped ascospore

(F) clear zone formation on iodine test
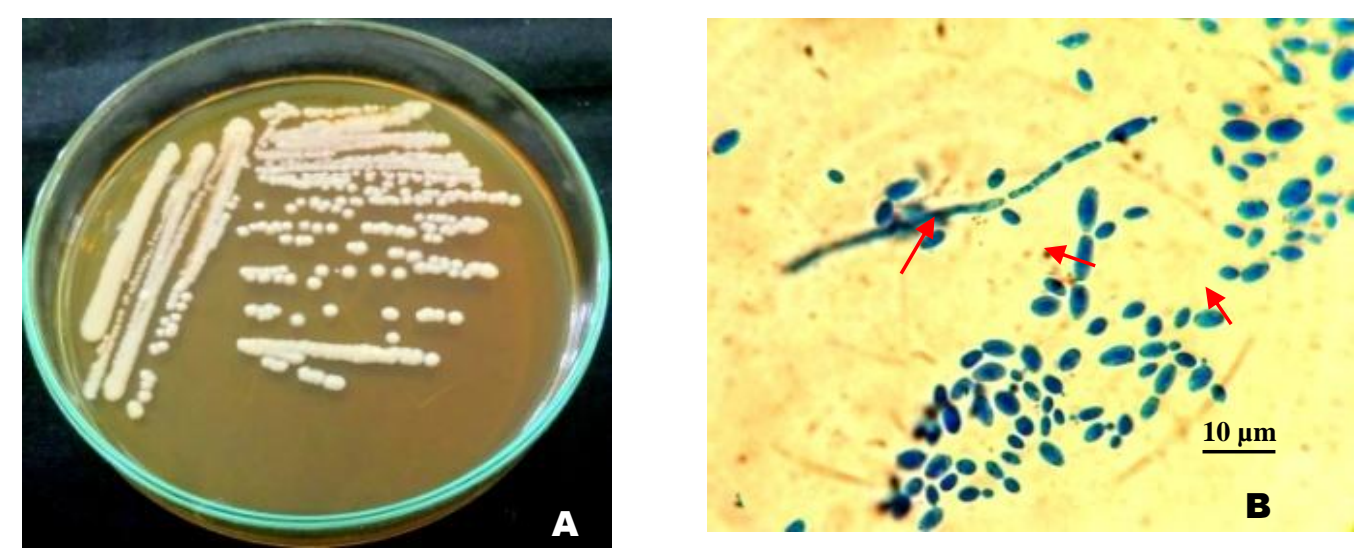

Fig.3 Macro and micromorphology of Candida tropicalis (A) pure culture on YEPD agar (B) budding cells, pseudohyphae and true hyphae

Isolates derived from all the seven districts revealed the presence of $S$. cerevisiae. Many worker reported $S$. cerevisiae as the dominant alcohol producing yeast in fermented products worldwide (Sujaya et al., 2004; Thapa and Tamang, 2004; Xie et al., 2007; do Amaral Santos et al., 2012; Jimoh et al., 2012; Miguel et al., 2013; Chakrabarty, 2017).
In the present study S. fibuligera was found to be associated with starter cultures from Jorhat, Golaghat and Sivasagar districts. S. fibuligera was the principal amylolytic yeasts found in Indonesian cassava-tape and ragi tape (Kuriyama et al., 1997). Many workers reported S. fibuligera from various fermented drinks (Tamang and Sarkar, 1995; Tamang, 2003; Thapa and Tamang, 2004; Tsuyoshi et 
al., 2005; Soka and Irene, 2013; Thakur et al., 2015). S. fibuligera produces large amount of amylases, acid protease and $\beta$-glucosidase which have high potential of applications in fermentation industry (Chi et al., 2009). It is also used to produce ethanol from starch, especially cassava starch by co-cultures of $S$. cerevisiae. It is probable that high yield of alcohol could be exploited by combining both the yeast. However, this is the first report of S. fibuligera from rice beer of Assam.

One Candida sp. was identified upto species level as C. tropicalis. Several workers also retrieved Candida spp. from fermented products (Hancioglu and Karapinar, 1997; Sujaya et al., 2004; Thapa and Tamang, 2004; Xie et al., 2007; Soka and Irene, 2013; Thakur et al., 2015; Chakrabarty, 2017).

The dominant yeast species associated with another Indian starter for rice wine from Manipur called 'Hamei' were identified as $S$. cerevisiae, Pichia anomala, Trichosporon sp., Candida tropicalis, Pichia guilliermondi, Candida parapsilosis, Torulaspora delbrueckii, Pichia fabianii and Candida montana (Jeyaram et al., 2008) which is in agreement with Balinese rice wine starter 'ragi tape' and Vietnamese rice wine starter 'mem' (Dung et al., 2006; Sujaya et al., 2004). In the present study domination of $S$. cerevisiae, S. fibuligera and Candida spp. in rice beer starter culture of Assam is in agreement with Sikkimish rice wine starter 'Marcha' (Tsuyoshi et al., 2005). From this, it is inferred that the yeast species associated with rice wine starter used in Himalaya regions (Assam, Sikkim) are distinctly differ from the starter used in Indo-Burma Biodiversity hotspot (includes Manipur, Vietnam and Indonesia of south eastern Asia) (http://www.biodiversityhotspots.org).

The study also revealed that the region within Himalayan-biodiversity hotspot, a consortium of $S$. cerevisiae and S. fibuligera may be a possible way of exploitation of yeasts species of the region to produce local wine of interest avoiding unwanted contaminants of the fermented products.

\section{References}

Ahmed, T., Chetia, S.K., Chowdhury, R. and Ali, S., 2010 Status Paper on Rice in Assam. Retrieved from http://www. rkmp.co.in

Barnett, J. A., Payne, R. W. and Yarrow, D., 1990. Yeasts: Characteristics and identification $\left(2^{\text {nd }} \quad\right.$ ed.) Cambridge: Cambridge University Press, pp. 1002.

Barnett, J.A., Payne, R.W. and Yarrow, D., 2000. Yeasts: Characteristics and Identification ( $3^{\text {rd }}$ ed.) Cambridge: Cambridge University Press.

Bhuyan, B. and Baishya, K., 2013. Ethno medicinal value of various plants used in the preparation of traditional rice beer by different tribes of Assam, India. Drug Invention Today. 5(4): 335-341.

Bora, S.S., Keot, J., Das, S., Sarma, K. and Barooah, M., 2016. Metagenomics analysis of microbial communities associated with a traditional rice wine starter culture (Xaj-pitha) of Assam, India. 3 Biotech. 6(2): 153.

Chakrabarty, J., 2017. Identification of Yeast Strain Isolated from Nduiyi of Dima Hasao District of Assam, India. Int. J. Curr. Microbiol. App. Sci.6(3): 587594.

Chavan, P., Mane, S., Kulkarni, G., Shaikh, S., Ghormade, V., Nerkar, D.P., Shouche, Y. and Deshpande, M.V., 2009. Natural yeast flora of different varieties of grapes used for wine making in India. Food Microbiol. 26: 801-808.

Chi, Z., Chi, Z., Liu, G., Wang, F., Ju, L. and Zhang, T., 2009. Saccharomycopsis fibuligera and its applications in 
biotechnology. Biotechnol. Adv. 27(4): 423-431.

do Amaral Santos, C. C. A., de Almeida, E. G., de Melo, G. V. P. and Schwan, R. F., 2012. Microbiological and physicochemical characterisation of caxiri, an alcoholic beverage produced by the indigenous Juruna people of Brazil. Intern. J. Jood Microbiol. 156(2): 112-121.

Dung, N.T. P., Rombouts, F.M. and Nout, N. J. R., 2006. Functionality of selected strains of moulds and yeasts from Vietnamese rice wine starters. Food Microbiol. 23: 331-340.

Dutta, H. and Mahanta, C. L., 2014. Traditional parboiled rice-based products revisited: Current status and future research challenges. Rice Sci. 21(4): 187-200.

Gilliland, R. B., 1971. Yeast classification. J. Inst. Brew. 77, 276-284.

Hancioglu, O. and Karapinar, M., 1997. Microflora of Boza, a traditional fermented Turkish beverage. Intern. J. Food Microbiol. 35: 271-274.

Jeyaram, K., Singh, M. W., Capece, A. and Romano, P., 2008. Molecular identification of yeast species associated with 'Hamei' - A traditional starter used for rice wine production in Manipur, India. Intern. J. Food Microbiol. 124: 115-125.

Jimoh, S. O., Saleh, A. A., Joseph, B. A. and Whong, C. M., 2012. Characteristics and diversity of yeast in locally fermented beverages sold in Nigeria. World J. Engg. Pure Appl. Sci. 2(2): 40.

Kuriyama, H., Satraatmadja, D., Igosaki, Y., Watanabe, K., Kanti, A. and Fukatsu, T., 1997. Identification and characterization of yeast isolated from Indonesian fermented food. Mycoscience. 38: 441-445.

Lodder, J., 1971. The Yeasts- a taxonomic study. North-Holland Publishing Company- Amsterdam. London.

Miguel, M. A. L., Peixoto, R. S., Rosado, A. S., Silva, J. T. and Paschoalin, V. M. F., 2013. Microbiological, technological and therapeutic properties of kefir: a natural probiotic beverage. Brazilian J. Microbiol. 44(2): 341- 349.

Robert Nout, M. J. and Kofi, E., 2015. Asian fungal Fermented Food. Mycota X: Industrial Applications. In: The Mycota - A Comprehensive Treatise on Fungi as Experimental Systems for Basic and Applied Research. Karl Esser (ed.), pp. 29-58.

Soka, S. and Irene, M., 2013. Molecular analysis of yeasts from Indonesian cassava and glutinous rice tapé. Food Sci. Biotechnol. 22(4): 993-997.

Spencer, J., Rawling, S., Stratford, M., Steels, H., Novodvorska, M., Archer, D.B. and Chandra, S., 2011. Yeast identification: reassessment of assimilation tests as sole universal identifiers. Lett. Appl. Microbiol. 53: 503-508.

Sujaya, I.N., Antara, N.S., Sone, T., Tamura, Y., Aryanta, W.R., Yokota, A. and Tomita, F., 2004. Identification and characteristics of yeasts in brem, a traditional Balanise rice wine. World J. of Microbiol. Biotechnol. 20:2, 143-150.

Tamang, J. P., 2003. Summary of ongoing projects: Microbial and biochemical studies of the traditional fermented beverages of the Darjeeling hills and Sikkim. Integrated Ecodevelopment Research Project (IERP) by G. B. Pant Institute of Himalayan Environment and Development, Almora, India.

Tamang, J. P. and Sarkar, P. K. Microbiology of murcha - an amylolytic fermentation starter. Microbios., 1995, 81: 115-122.

Thakur, N., Saris, P. E. and Bhalla, T. C., 2015. Microorganisms associated with amylolytic starters and traditional fermented alcoholic beverages of North 
Western Himalayas in India. Food Biosci. 11: 92-96.

Thapa S. and Tamang J. P., 2004. Product characterization of kodo ko jaanr: fermented finger millet beverage of the Himalayas. Food Microbiol. 21: 209213.

Tsuyoshi, N., Fudou, R., Yamanaka, S., Kozaki, M., Tamang, N., Thapa, S. and Tamang, J. P., 2004. Identification of yeast strains isolated from Marcha in Sikkim, a microbial starter for amylolytic fermentation. Intern. J. Food Microbiol. 99(2): 135-146.

Wickerham, L. J., Lockwood, L. B., Pettijohn, O. G. and Ward, G. E., 1944. Starch hydrolysis and fermentation by the yeast Endomycopsis fibuliger. $J$. Bacteriol. 48: 413-427.

Xie, G., Li, W., Lu, J., Cao, Y., Fang, H., Zou, H. and $\mathrm{Hu}, \mathrm{Z} ., 2$ 2007. Isolation and Identification of Representative Fungi from Shaoxing Rice Wine Wheat Qu Using a Polyphasic Approach of Culture-Based and Molecular-Based Methods. J. Inst. Brewing. 113(3): 272279.

Yarrow, D., 1998. Methods for the isolation, maintenance and identification of yeasts. In: The Yeast, A Taxonomic Study, Kurtzman, C.P., Fell, J.W. (eds.). Elsevier Science, Amsterdam, pp. 77105.

\section{How to cite this article:}

Saikia, B., M.S. Ali, P.D. Nath and Dey, P.C. 2019. Exploring the Yeast Diversity of Common Alcoholic Beverages of Assam. Int.J.Curr.Microbiol.App.Sci. 8(05): 1519-1527. doi: https://doi.org/10.20546/ijcmas.2019.805.175 